\title{
Blood, Sweat and Tears. The Martyred Body in Chinese Performance Art
}

Tania Becker

When we speak of offending images in the context of contemporary Chinese art, some of us may remember articles that were published in $200 \mathrm{I}$, voices of outrage in reaction to Zhu Yu's performance Eating People:

\section{Is it art when a man eats a dead baby?}

LONDON - My God, what kind of society do we live in? A Chinese man eats a dead baby on TV and actually claims it's art! The announcement alone unleashed one of Great Britain's hottest debates on the freedom of the media, the press, and art: the British TV Channel 4 wanted to broadcast the documentary Beijing Swings, which includes photographs of Chinese artist Zhu Yu apparently eating a dead baby. According to Zhu, the corpse is from a miscarriage. In one of the photographs, he's washing the body in a sink. Another photo shows him biting into a dismembered body part. Zhu has said that the pictures were taken during a performance titled »Eating Humans« in his house in Beijing. Yesterday, Zhu Yu claimed that as an artist, it's his job to initiate debates over morality and art. His work involves exploring whether boundaries still exist. It does not, however, seem to bother anyone when this »artist « transgresses these boundaries. Not even the guardians of the law - because despite the fact that artists using human body parts for their art can be sentenced to ten years in prison, nothing happened [...]. 
After the images made the rounds in the Internet, the shocking act of consuming a fetus met with reactions worldwide. А BBC documentary on the artist Zhu Yu from 2003 also provoked a powerful reaction and unleashed a series of stormy debates. To be sure, violating the taboo against cannibalism, as was documented in the aesthetically reduced images of the performance Eating People, is deeply disturbing effect because its brutality exceeds all we have experienced in art. Other performances and installations by Chinese artists that were realized during this time at the turn of the millennium also feature bodily excesses and a shocking, taboo-violating approach to corporeality. Subtle allusions are seldom used; instead, Chinese performance artists often use animal cadavers or human corpses as well as their own bodies to probe habits, moral attitudes, and the boundaries of the socially acceptable. These performances are often understood as reflections of the country's econoic and socio-political changes. Yet, despite their clear, radical, and uncompromising criticism of political circumstances and the shocking social provocations, the most successful of these works remain ambivalent and resist a one-dimensional, glib interpretation.

This paper introduces two of the leading and most radical Chinese performance artists, Zhu Yu 朱昱 (born in 1970) and Yang Zhichao 杨志超 (born in 1963), together with their artistic activities in the context of the political situation and social transformation in China. To better understand these artists' work, the following offers a brief overview of the most important historical events generally regarded as seminal in the development of contemporary Chinese art. 


\section{Past History}

Over the past three-and-a-half decades, contemporary Chinese art has accompanied a number of important political-historical events, reflected upon them, and arrived at its own conclusions. Beginning in 1979, these political occurrences have taken place with an almost regular rhythm of decade-long intervals.

\section{I979}

Following the end of the Cultural Revolution, and more pronouncedly immediately after Deng Xiaoping 邓小平 (1904 - 1997) opened up the country, the situation of the Chinese art scene changed. In the late 1970s, some artists were granted permission to travel to Europe and the USA for study purposes. At the same time, exhibitions, art publications, and art magazines featuring contemporary »Western« art and art theory were tolerated for the first time. Two artists' associations were formed that would be influential in the subsequent development of contemporary Chinese art: Stars (Xingxing buabui 星星画会) and Scar Painting (Shangben buibua 伤痕绘画). While the first group borrowed from the traditions of European Classical Modernism, was influenced by Post-Impressionist and Abstract Expressionist techniques, and consequently produced experimental works in a modernist style, the artists of Scar Painting oriented themselves toward more well-known forms of realism and Socialist Realism. They introduced an entirely new set of themes that embodied a critical examination of the Cultural Revolution.

In their political leanings, both groups existed in the context of the »Beijing Spring « of the late 1970s. This citizens' movement became known through one of its main figures, Wei Jingsheng 魏京生 (born in 1950), who was sen- 
tenced to is years in prison and labor camp as a result of his call for democracy at the »Xidan Wall of Democracy« (Xidan minzbu qiang 西单民主墙). The »Wall of Democracy « provided an opportunity for artists and political activists to articulate their demands for freedom of expression and artistic freedom. ${ }^{2}$

In addition, numerous debates over art's role and function took place in art magazines, where makers of culture expressed their longing for artistic freedom. Later, however, these efforts would prove detrimental to their further activities. Officials soon prohibited the artists' protests at the »Wall of Democracy.« Nonetheless, these protests, in the form of exhibitions organized ad hoc, can be considered the first cautious beginnings of what would later develop into a new Chinese art. ${ }^{3}$

In the first half of the 1980 s, state repressions intensified. During the »Campaign Against Spiritual Pollution« (Qingchu jingshen wuran 清除精神污染, 198384), contemporary art was defamed as »bourgeois, « several exhibitions shut down, and the editorial offices of renowned art magazines, such as Meisbu 美术 (Fine Arts), were re-staffed with cadres true to party principles. Planned exhibitions were cancelled and prohibited, and consequently many artists left the country. ${ }^{4}$

\section{9}

Through the activities of the artists' group Stars, experimental forms that had not yet been officially accepted in the art academies became more or less recognized. As a result, a »new wave of artistic expression began to establish itself, especially among art students and graduates, which culminated in a network of new movements, groups, exhibitions, and individual efforts and became known as the $85 \mathrm{New}$ Wave Movement (85 xincbao yundong 85 新潮运动). 
This consisted of approximately 80 groups from various regions across China whose members were young artists who came together between 1984 and 1986.5 This artists' movement had no particular program; nor did it have a coherent artistic direction. It invoked primarily Dadaism, and Marcel Duchamp (1887 - 1968) in particular, as well as American Pop Art of the 1960s and contemporary action art. ${ }^{6}$ In contrast to the artists from the late 1970 , the artists of the 85 New Wave Movement were better informed about current developments in Western art and saw themselves as reformers of Chinese art.

The group succeeded in organizing several important exhibitions, including a controversial show in 1989 known by the name China / Avant-Garde.7 Following numerous discussions and bitter battles, it opened in the halls of the state-run National Art Museum in Beijing. Following an incident, however, it had to be temporarily closed after only a few hours. ${ }^{8}$ With their commitment, the vehemence of their artistic expression, and their geographical proximity, the 85 New Wave Movement group also made an active contribution to the protests at Tiananmen Square in June 1989, which took place only a few months after the exhibition opened. It was no accident that the most important events in Chinese avant-garde art and the democracy movement at Tiananmen Square in Beijing coincided in time and space. Both had been made possible by an influx of information from abroad, and both were driven by a desire to loosen calcified political structures and a common zeal to put an end to authoritarianism and conformism in society and to establish new forms of behavior. ${ }^{9}$

In the years following the suppression of the protest movement at Tiananmen Square, the regime redoubled its efforts to prohibit all artistic activities that diverged from traditional panel painting, sculpture, and calligraphy - in 
other words installations and video, action, and multimedia art. Because of its immediacy and emotional charge, the regime regarded performance, in particular, as suspicious and socially dangerous. When artists nonetheless engaged in this type of artistic expression, their actions had to be carried out quickly and in secret. The consequences of the official restrictions were a marginalization of their work and a constant threat and danger of incarceration. Throughout these years, many withdrew into private life or emigrated abroad. Nearly no exhibitions took place in public space. ${ }^{10}$

Hou Hanru 侯瀚如 (born in 1963), one of the organizers of the exhibition China / Avant-Garde, commented on the events of the post-1989 era:

Chinese society of the r 990 s is marked by an interesting contradiction: despite the far-reaching economic liberalization, official control in the area of ideology was never loosened. The possibilities for experimental artists to express themselves within institutions hardly improved. ${ }^{I I}$

Another art genre that arose in the early 1990 s is known as »Political Pop« (Zhengzhi bopu 政治波谱). Coined in 1992, this term stood for the art movement that was oriented toward the colors and forms of American Pop Art of the 1960s. ${ }^{12}$ In thematic terms, Chinese Political Pop brought together elements of Socialist Realism and the lightness of motifs from Western Pop Art; at the same time, however, it criticized the similarities between the ideological power of advertising and that of political propaganda, particularly that of the Cultural Revolution. The artists of Political Pop distorted their motifs using irony, cynicism, parody, and playfulness, and they suggestively 
conveyed the feeling of the chaotic political and economic conditions in Chinese society that followed the repression of the protest movement at Tiananmen Square. At first, the works of this art movement were hindered by officials, but since the 1993 exhibitions China Avantgarde in Berlin and Passagio da Oriente in Venice, the first major exhibitions of contemporary Chinese art in Europe, as well as Mao Goes Pop in Sydney, the works of Political Pop also found gradual acceptance in China. Demand grew, and they now command high prices on both the national and the international art markets. ${ }^{13}$

\section{An Uncooperative Approach}

\section{0}

A clear shift from previous exhibition practice occurred with Fuck off or $A n$ Uncooperative Approach (Bu bezuo de fangsbi 不合作的方式). As part of the Third Shanghai Bienniale in 2000, this exhibition, curated by Ai Weiwei 艾未未 (born in 1957) and Feng Boyi 馮博一 (born in 1960), featured works by a total of 47 artists. Although An Uncooperative Approach was one of the many satellite exhibitions of the Shanghai Bienniale, it received an enormous amount of publicity, not least due to its provocative agenda, expressed in a series of extremely controversial and, for the time, shocking works of art, performances, and installations and turned ostentatiously against the commercialization of art and the authoritarian discourse of the system. ${ }^{14} \mathrm{I}$ do not care to speculate on the origins of this era of shock or the violence in the respective works, which were often directed at the artist's own body. I can, however, see certain ref- 
erences to recent Chinese history and to a kind of compensatory physical pain directed against the restrictions imposed by the ever-present political and thematic domination. Evidently, the ambivalence between a rapidly growing Chinese art industry and an authoritarian domination exerted by a cultural bureaucracy loyal to the Party leads to periodic phases of freedom in expression, followed by phases of repression. In an interview, Ai Weiwei explained the concept behind An Uncooperative Approach:

We were very clear about what we wanted to say towards Chinese institutions as well as Western curators and institutions and dealers; their functions are very similar in one way or another. It's all about the deal, about labor, about how to trademark different interests. We had to say something as individual artists to the outside world, and what we said was »fuck off. «15

Although the exhibition was shut down after only a few days due to several disturbing performance photos of the artists Zhu Yu and Yang Zhichao, ${ }^{16}$ it nonetheless left an indelible mark in the history of contemporary Chinese art. From this point on, inspired in its expressive forms by Western art movements of the second half of the $20^{\text {th }}$ century (such as performance, conceptual art, happening, video, and multimedia installation), the progressive »unofficial $\ll^{17}$ Chinese art scene turned away from both its own traditional antecedents and the classical Western modernist paragons. Instead, artists explored new, experimental, individual forms and themes, always in relation to the current political-social reality in the country. Deconstruction, parody, and criticism of the 
current social and political problems counted among the challenges of these independent artistic positions that had freed themselves from the old patterns, as curators Ai Weiwei and Feng Boyi assert in the foreword to the exhibition:

Fuck off emphasizes the independent and critical stance that is basic to the existence of art. Within a state of countless contradictions and conflicts, it maintains its status of independence, freedom, and plurality. It tries to provoke an artist's responsibility and self-discipline, searches for a way in which art lives as »wildlife, « and raises questions about some issues of contemporary Chinese art. ${ }^{18}$

As a result of the works' vehemence, dynamics, and direct nature, the exhibition led the way to lasting change. It helped bring about an increase in exhibition activity in China, after which contemporary art soon began attracting greater public attention. The official reactions to these testimonies to an increasing intellectual independence in individual artistic approaches, which clearly positioned themselves against marketing and political dominion over the field of art, ranged from controlled tolerance to open repression - attesting to the importance of this cultural sector for assisting state organs of control in interpreting social consciousness. ${ }^{19}$

\section{Blood, Sweat and Tears: Chinese Performance}

Yang Zhichao's and Zhu Yu's performances, which were put on exclusively for the Fuck off exhibition, were the main cause of the show's premature closure. 
After the two artists' performative acts were presented and then documented and exhibited in the form of two photo series, the arrangements, which aimed to shock, cause pain, and violate taboos, gave rise to numerous polemics and protests, also in international art criticism. ${ }^{20}$ Before I discuss these works more closely, I'd like to examine the special nature of performance as a form of art situated between ritual, spectacle, and show.

\section{Performance}

A performance is an artistic event, an open process that occurs in a place and time that belongs to it alone, and because it can never be repeated in exactly the same way, both performer and viewers experience it exclusively at the moment it takes place. In most cases, performance requires the physical presence of the artist, who functions as a medium by carrying out a calculated activity in a direct manner. Thus, the artist goes beyond mere physical presence and, in the moment of occurrence, on a physical level, forges an intense relationship with his or her viewers. Due to its inherently contradictory nature, the experience that ensues between artist and audience becomes the most important component of a performance, which in certain cases can resemble a social experiment in whose course the conscious states of everyone present undergo change. ${ }^{21}$ While happenings involve viewers directly in the event by provoking a variety of reactions, which become a component of the artistic statement, a performance is an act carried out without the direct involvement of the audience. The fundamental elements of both of these forms of expression, happening and 
performance, are the merging of time and space and the uniqueness and immediacy of the acts performed, which draw on the body and language of the artist. ${ }^{22}$ The beginnings of Chinese performance art (xingwei yishu 行为艺术) date back to 1985 and the early actions of Chinese artists, for example the group Xiamen Dada 厦门达达 and Zhang Huans 张洹 (born in 1965). Following the suppression of the protest movement on Tiananmen Square, many artists withdrew and created experimental works and carried out art actions that met with recognition in small groups outside the academies. ${ }^{23}$ Thus, in an authoritarian post-1989 environment, performance developed into a critical new voice of the younger generation that possessed social and political potential. Unfit for the academies and rejected by official cultural policies, these artists withdrew from the wider public eye to a private context and carried out their actions and concepts for small groups of viewers and often without any audience at all. ${ }^{24} \mathrm{~A}$ short time later, that is to say in the r990s, some Chinese performers became known abroad through their own travels and actions and thus became a recognized part of a small international art scene involved in avant-garde performance art. ${ }^{25}$ Western reactions to later Chinese performance actions vacillated between disgust and irritation; this helped Zhu Yu in particular, whose performance Eating People attained a degree of notoriety, despite the fact that performance art from China still interested a relatively small number of people and experts at the time, around 2000.

A wider public for performance did not yet exist. When Western interest in the beginnings of contemporary Chinese art grew some years later, it was particularly the actions from around 2000 that met with great interest; by this time, however, this intense period of Chinese performance art had already come to an end. Performance art in China is not an imported product or an imitation 
of Western art. ${ }^{26}$ Closely tied to the current realties in the country, Chinese performance developed its own independent vocabulary: in its criticism of current social and political conditions, it seeks an open confrontation with traditions, norms, history, and human and civil rights. Subtle allusions are rare; instead, Chinese performance artists often use shock effects, for instance the aforementioned artist $\mathrm{Xiao} \mathrm{Lu}$, who fired two shots into her own installation with a revolver during the opening of the 1989 exhibition Cbina / Avant-Garde in Beijing. ${ }^{27}$ Radical and uncompromising in their actions, Chinese artists often stage animal cadavers or human corpses and their own bodies to explore the boundaries of habit, morality, and the socially acceptable. ${ }^{28}$ Yet, despite their cogent criticism of political conditions and grievous social provocations, the most successful works remain ambivalent and resist any glib, one-dimensional interpretation.

Yang Zhichao and Zhu Yu are probably the two most prominent figures in this tendency in Chinese performance art. Both artists work with and through their bodies and deliberately and actively subject themselves to considerable emotional and physical pain, whereby their controversial actions are exclusively directed at a concrete and intensified corporeality.

\section{Yang Zhichao}

»At I0:00 A.M. on November 5, 2000, on the second floor of No. ${ }_{1} 33$ Suzhou Road in Shanghai where >Fuck off $<$ was on show, I made an operation platform $200 \times 80 \times 78 \mathrm{~cm}$ in size, on which a surgeon used a scalpel to make an incision in my left scapula. Without any anesthesia, the scalpel made two cuts one centimeter deep and one centimeter wide. Afterwards, grass picked at the 
banks of the Suzhou River was planted into the two cuts.« ${ }^{29}$ Yang Zhichao's short, precise description of his performance Planting Grass, Zbong cao 种草, sounds like a scientific report of a surgical procedure; it allows no space for emotional or personal interpretation (Fig. I).

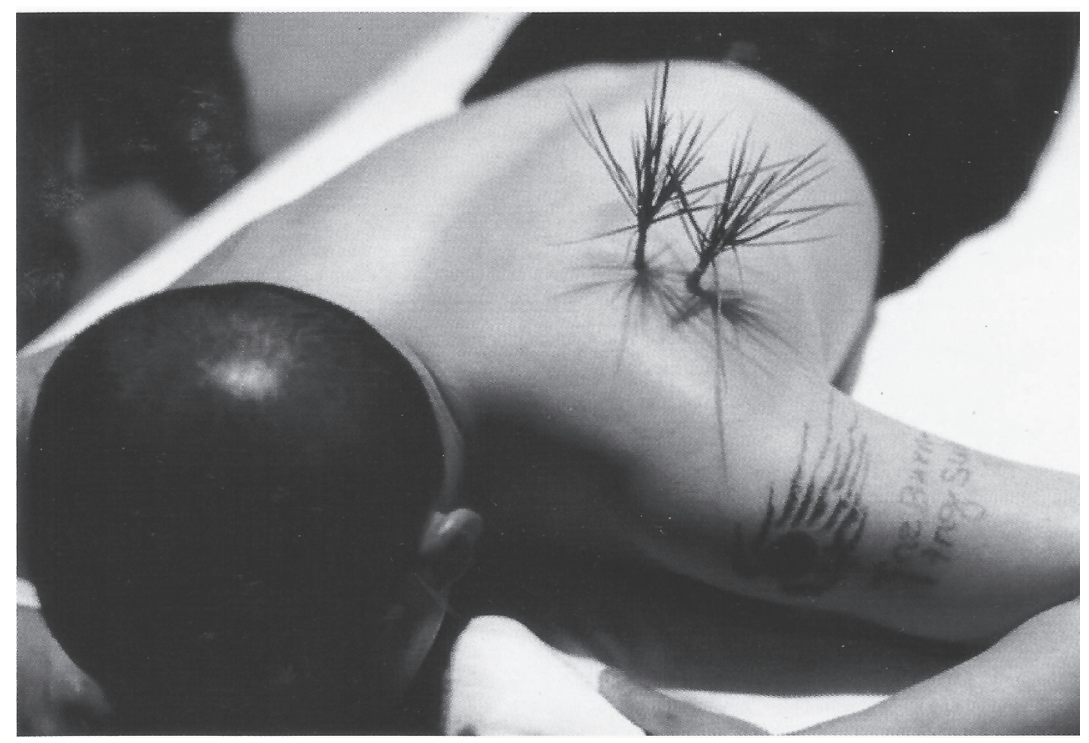

[FIG. 1]

Yang Zhichao: Planting Grass (performance documentation), Nov. 5, 2000, Suzhou Road, Shanghai

Nonetheless, this act of public injury to the artist's own body offers enough potential for a reading that goes beyond the disintegration of the physical and finds its true meaning in a political demonstration. By artificially connecting two life forms - human and plant — Yang investigates how different species behave toward one another in such a changed state. In this altered context, the 
human body and the blades of grass take on a new referentiality, just as in the socio-political realm the penetration of new elements into existing political structures inevitably transforms the latter. In employing this drastic metaphoric structure, Yang makes a case for changing his country's political system, which has the potential to develop in a positive direction through a newly gained freshness and vitality, symbolized here by grass. In this respect, Yang's concept of the body goes beyond biology into the realm of the political. By interpreting the body as an extension of society and the state, the artist addresses numerous questions from the border zone between biology and politics: what is the body? Whom does it belong to? To what extent is it possible to retain control over what happens to one's body? Taken to its provocative conclusions, the performer poses the question of our understanding of human freedom beyond a view of the world that is reduced to scientific categories..$^{3 \circ}$ In this way, Yang's performance carries on a dialogue about the body and his country, and beyond this, about China's position in the world.

The blades of grass were inserted into the performer's body through precise surgical incisions, which were carried out professionally, but not in sterile conditions. The artist accepted the risk that he might fall prey to a dangerous infection; he regarded it as part of the project. Body and grass entered into a symbiosis and formed an astonishing new biotope that gave rise to a palpable experience of earth, grass roots, and blades of grass on and beneath the skin. The growth of the grass and the time this requires transform the momentary into duration and the performance itself into a work in progress. The deviance of the bodily state (body modification) that the action is based on resides in a biophysical dialogue between the body and grass taken from a nearly river bank..$^{31}$ 
In this sense, the artist takes a position against the increasing change in the natural environment and the expulsion of natural biotopes, as well as the negative effects of rapid economic growth: the performance highlights the fragility of human existence in an altered living environment.

While the artist does not express it in his behavior, but nonetheless feels it, the obvious presence of pain is an essential, if not the most essential part of the performance. In general, in the various ways they are mentally dealt with, experiences of pain often lead to questions of meaning that must, however, be understood as culturally determined in a very specific way. ${ }^{32}$ Yang's performance goes against this cultural anthropological interpretation, however, because his additional message consists in attaining a sensory knowledge that is not learned through theory, but can only be understood through direct existential experience, which in this case is the experience of pain. Yang Zhichao is not merely interested in an unequivocal demonstration, but rather in the actual, unavoidable phenomenon of bodily pain, which goes beyond specific cultural boundaries:

Only the personal experience of pain lets me achieve insights which cannot be reached on the level of abstraction. Pain is a way to reach another feeling of life. By removing the taboo from the theme "pain« and by presenting pain to the public, I hope for an international dialogue. The basic experience of mental and physical anguish knows no national borders. ${ }^{33}$

\section{Zhu Yu}

One month before the exhibition opening in Shanghai, a series of photographs was taken in the home of the artist Zhu Yu that documented his action Eating 
People (Shi ren, 食人). The invitation to take part in the exhibition provided the occasion for the artist's action. Because the curator Ai Weiwei surmised that Zhu Yu's work would provide the authorities with one of their most convincing reasons to shut down the exhibition ahead of time, the photographs were not shown openly, but were put in a black box. It was only after the images were introduced to the public via the catalogue that the provocative nature of the action gained instant notoriety. Within a very short time, the visual documentation made the rounds in the Internet and attracted a wave of global attention. ${ }^{34}$

The short title already hints at the performance's scope and demonstrates the artistic act's transgressive implication: Zhu Yu is photographed cooking a human fetus, serving it on a plate, and finally consuming it (Fig. 2). Cannibalism is recorded in cool, reduced images entirely without commentary. For the photograph's viewers, the visual impact of this distanced visual documentation, paired with the intense, taboo-violating, brutal cannibalistic act performed in real life immediately evokes feelings of disgust, revulsion, and an unwillingness to understand. At the same time, other feelings are also evoked, such as fascination and curiosity. Through a combination of two contradictory impressions, confronted by a documented violation of a basic taboo and oscillating between aversion and attraction, the viewer winds up in a paradoxical position.

In this performative act of infantiphagia, the artist manipulates the body of another person robbed of free will and all human interaction. The situation created is one of hopelessness and arbitrariness. The unborn child becomes a victim of events and the recipient of empathy. Zhu Yu's performance is also a self-experiment; not only does he exploit the fetus manipulatively, he manipulates and explores his own body on a psychosomatic level, as well. 


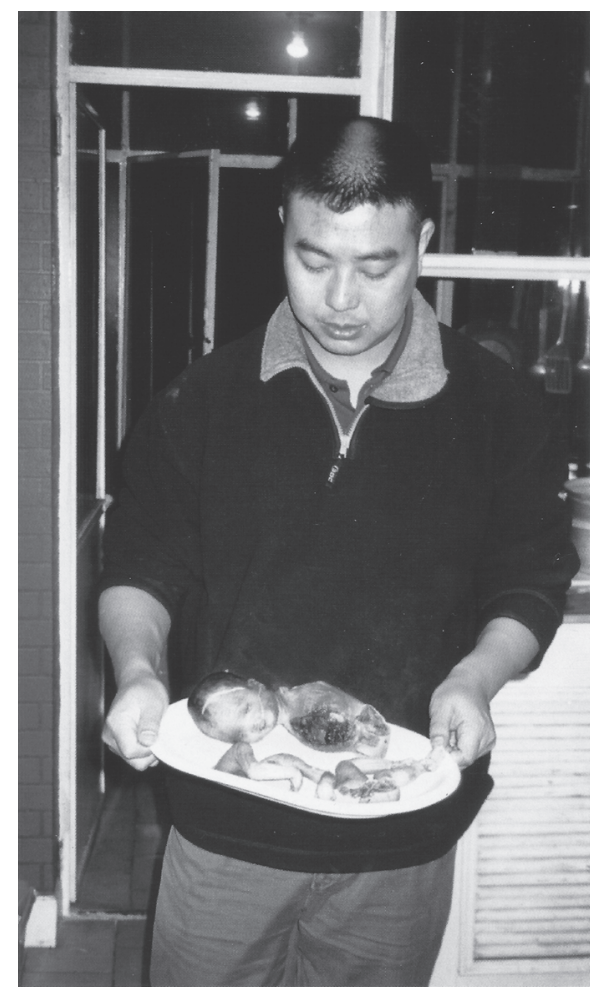

[FIG. 2]

Zhu Yu: Eating

People (performance

documentation), Sept.

2000, Shanghai

According to his own statements, he had to vomit twice while carrying out the performance, and upon its completion, he was so emotionally depleted by the act that he was unable to work in his studio for a long time. ${ }^{35}$ Evidently, with this defensive response, his body reacted more powerfully to the violation of taboo than the artist himself had intended..$^{36}$

In this disturbing and brutal violation of taboo, evident as such from all cultura and anthropological perspectives, the artist undoubtedly transgresses 
ethical boundaries. His action, however, recalls the radicalism and brutality of the bio-political family planning policies enforced with unparalleled ruthlessness and severity in the People's Republic of China from 1979 on, as well as earlier epochs in China's history, which saw drastic periods of famine, cannibalism, and the consumption of babies' corpses. ${ }^{37}$

The transgression of ethical norms with the aim of questioning them; highlighting violence and fear; a clear criticism of the socio-political situation in the People's Republic of China: these are some of the possible ways to interpret Zhu Yu's performance. The artist cites additional aspects when he describes the motivating forces behind the action:

One question that always stymies us - that is, why cannot people eat people? Is there a commandment in man's religion in which it is written that we cannot eat people? In what country is there a law against eating people? It's simply morality. But, what is morality? Isn't morality simply something that man whimsically changes from time to time based on his/her own so-called needs of human being in the course of human progress? From this we might thus conclude: so long as it can be done in a way that does not commit a crime, eating people is not forbidden by any of man or society's laws or religions; I herewith announce my intention and my aim to eat people as a protest against mankind's moral idea that one cannot eat people..$^{8}$

In his performance, Zhu Yu inquires into the foundations of morals, laws, and norms. If there is no law against cannibalism, does this mean that it's legal, 
rather than a crime? In precisely this trenchantly inhumane act of cannibalism, he makes a plea for a humanity that should be intrinsic to legal norms and develop in tandem with ethical, cultural, and historical conditions. Thus, the naked ingesting of a fetus transforms into an epistemological study of existing social and normative structures. Zhu Yu's performance Eating People, in addition to its provocation of general notions of morality, is also an appeal to fundamentally question the existence or nonexistence of social taboos; against norms lacking in substance; and for a free and public discourse that can also be interpreted on a political level. A problem emerges here, that of a misguided biopolitics all too quick to serve pragmatic and specific interests without first securing the foundation of a universal humanity.

Yang Zhichao's and Zhu Yu's performative actions allow us to consider whether the increase in cruelty in Chinese art presentations has perhaps goaded itself on and resulted in radical outgrowths, culminating in the violation of the cannibalism taboo in Zhu Yu's work. ${ }^{39}$ Even if actions such as these are extreme examples, when one considers the developments in contemporary Chinese art, the impression arises that dynamic exists that are both creative and destructive. And it's these heterogeneous artistic approaches that reflect the evident sensibilities of a society torn between the competing gravitational centers of a fastmoving socio-economic dynamic and a traditionally dogmatic, power-obsessed state apparatus: the revolutionary political force that nationalists and communists once unleashed continues to this day, accelerated by the economy and refuting yesterday's certainties on a daily basis. 
1 Quote from the online issue of Berliner Kurier, January 4, 2003 , http://www.berliner-kurier.de/archiv-ist-das-nochkunst-wenn-ein-mann-eine-baby-leiche-isst-,8259702, $4245234 \cdot h t m l$ (accessed on June I3, 2016).

2 The Stars also wrote critical commentaries on the »Wall of Democracy« and organized a spontaneous open-air exhibition on September 27, 1979 that was immediately prohibited. During a demonstration on October I, 1979, slogans such as »demand political democracy, demand artistic freedom « were chanted. The protest met with unexpected consequences: the authorities granted them a ten-day exhibition in a hall belonging to one of Beijing's art associations at Beihai Park. The show drew 40,000 visitors; due to its great success, the artists were allowed to show 149 of their works the following year. This time, 80,000 visitors saw the exhibition. Thomas J. Berghuis: Performance Art in China, Hong Kong 2006, pp. 43-46; Richard Vine: New China, New Art, Munich, New York 2008, p. I3.

3 Maria Esposito: Inside Out. Neue chinesische Kunst, http:// www.wsws.org/de/200I/junzoor/chin-jor.shtml (accessed on June $\left.1_{3}, 2016\right)$.

4 Ibid. Among the artists who emigrated are Ai Weiwei 艾未 未 (born in 1957) and Wang Keping 王克平 (born in 1949), as well as Huang Rui 黄锐 (born in 1952) of the Stars. Berghuis: Performance Art in China (see note 2), p. 47 .

5 Wu Hung/Peggy Wang: 85 Art New Wave, in Hung/Wang (eds.): Contemporary Chinese Art. Primary Documents, New York and Durham 20I0, pp. 5I-52.

6 Vine: New China, New Art (see note 2), p. I4.

7 Officially, the name of the exhibition was Exbibition of Modern Cbinese Art (Zhongguo xiandai yishuzhan 中国现代艺术展).
8 The exhibition was cancelled due to the action of Xiao Lu 肖鲁, an action artist who fired two shots at her installation Dialogue (Duibua 对话), a collaboration with Tang Song 唐宋 that was classified as subversive. See Hang Jian / Cao Xiao'ou: A Brief Account of China/Avant-Garde, 1989; Hung/Wang (eds.): Contemporary Chinese Art. Primary Documents (see note 5), Pp. I2I-I26; Uta Grosenick / Caspar H. Schübbe: China Art Book, Cologne 2007, p. Io.

9 Vine: New China, New Art (see note 2), P. I4.

${ }^{10}$ Yilmaz Dziewior: Zhang Huan, Ostfildern-Ruit, London 2002 , p. 8 .

11 Hou Hanru: Die Leere der Großstadt anfüllen - urbane Explosion und künstlerische Intervention in chinesischen Städten, in Kai Vöckler (ed.): Peking, Shanghai, Shenzhen. Städte des 2I. Jahrhunderts, Frankfurt am Main 2000, p. 189.

12 Berghuis: Performance Art in China (see note 2), p. 93, note 176.

13 Artists such as Yu Youhan 余友涵, Wang Guangyi 王广义, Li Shan 李山, Zhang Xiaogang 張曉剛, Yue Mingjun 岳敏 君, Zhou Tiehai 周铁海, and Fang Lijun 方力均 i.a. can be regarded as representatives of this direction; see Political Pop: Zhengzhi popu 政治波谱, in Art Speak China, Tan yishu 谈艺术, http://www.artspeakchina.org/mediawiki/ index.php/Political_Pop_政治波谱(accessed on June 13, 2016). See Wu Hung / Peggy Wang: Chronicle 1976-2006, in Hung / Wang (eds.): Contemporary Chinese Art. Primary Documents (see note 5), p. 420; Episode 38/1993: China Avantgarde! An exhibition, power, and the market, Haus der Kulturen der Welt, http://www.hkw.de/de/hkw/gebauede /50/1993.php (accessed on June I3, 2016).

14 Ai Weiwei / Feng Boyi: Preface to Fuck off, 2000, in Hung/ Wang (eds.): Contemporary Chinese Art. Primary Documents (see note 5), pp. 354-355. 
15 Chin-Chin Yap: Conversations. Interview with Ai Weiwei, in Ai Weiwei/Charles Merewether(eds.): Ai Weiwei. Works, Beijing $1993^{-2003}$, Hong Kong 2003 , p. 51 .

16 Berghuis, Performance: Art in China (see note 2), P. I52; Vine: New China, New Art (see note 2), pp. I04-IO5.

17 According to John Clark's analysis of conditions in the Chinese art scene at the beginning of the 2ist century, the main difference between »official« and »unofficial« contemporary Chinese art does not lie in the difference between the avant-garde and established art, but rather in the varying acceptance of different forms of artistic expression within the political system. John Clark: System and Style in the Practice of Chinese Contemporary Art. The Disappearing Exterior «, Yishu 艺术, in Journal of Contemporary Chinese Art, I/2 (2002), Pp. 13-33.

18 Ai / Boyi: Preface to Fuck off(see note I4), p. 355.

19 Berghuis: Performance Art in China (see note. 2), Pp. I5I-I52; Vine: New China, New Art (see note 2), p. I4.

${ }^{20}$ Ibid., p. 162.

${ }^{21}$ Erika Fischer-Lichte: Ästhetik des Performativen, Frankfurt on the Main 2004, PP. $3^{1-42 .}$

22 Helge Meyer: Schmerz als Bild. Leiden und Selbstverletzung in der Performance Art, Bielefeld 2008, pp. 28-29.

${ }^{23}$ Berghuis: Performance Art in China (see note 2), pp. $25-27$.

${ }^{24}$ Ibid, pp. I8I-183. One of the most consistent works of this kind that took place in a non-public space and without an audience was Jiayuguan 嘉峪关 (December 3, 1999January 30,2000 ) by Yang Zhichao. The artist had himself committed to a psychiatric hospital in the city of Jiayuguan,
Gansu for one month, to live as a healthy person among the other patients. This long-term performance was partially filmed with a hidden camera by relatives who visited him on a regular basis and offers an extremely rare glimpse into the state of the psychiatric health of Chinese society. Meyer: Schmerz als Bild (see note 22), p. 259.

${ }^{25}$ Kristine Stiles: Afterword: Quicksilver and Revelations: Performance Art at the End of the Twentieth Century, in Linda Montano (ed.): Performance Artists Talking in the Eighties, Berkeley 2000, p. 479.

${ }^{26}$ Ibid., p. 479 .

${ }^{27}$ Berghuis: Performance Art in China (see note 2), pp. 90-91.

${ }^{28}$ Carlos Rojas: Cannibalism and the Chinese Body Politic. Hermeneutics and Violence in Cross-Cultural Perception, in Postmodern Culture 12/3 (2002) http://pmc.iath.virginia. edu/issue.502/12.3rojas.html (accessed on June I3, 2016).

${ }^{29}$ Yang Zhichao quoted by Meyer: Schmerz als Bild (see note 22), p. 256 , footnote 20.

30 Meyer: Schmerz als Bild (see note 22), p. 258.

31 Ibid., p. 256.

32 David B. Morris: Geschichte des Schmerzes, Frankfurt on the Main 1996, p. 43.

33 ThreeArtists, in transgressivechineseart, http://transgressive chineseart.wordpress.com/tewlt4/ (accessed on June I3, 2016).

${ }^{34}$ Meiling Cheng: Violent Capital. Zhu Yu on File, in The Drama Review, 49/3 (2005), pp. 58-77, here pp. 6I-62. 
35 Ibid., p. 7I.

${ }^{36}$ Meyer: Schmerz als Bild (see note 22), pp. 246-247.

37 Excesses of this kind continued to take place, for instance during the Great Leap Forward, a campaign that ran from 1958 to 196I during whose course one of the greatest famines in modern history took place. Caused by bad political decisions and grave natural catastrophes, the number of people who starved to death is estimated at 45 million. See Frank Dikötter: Mao's Great Famine. The history of China's most devastating catastrophe, 1958-62, London 2011, Pp. 320-323; Jasper Becker: Hungry ghosts. Mao's secret famine, New York 1998, Pp. 21I-213.

${ }^{38}$ Quoted in Rojas: "Cannibalism and the Chinese Body Politic« (see note 28 ).

39 Meyer: Schmerz als Bild (see note 22), p. 249. 